\title{
Influence of Oxygen and Temperature on the Respiration Rate of Fresh-cut Cantaloupe and Implications for Modified Atmosphere Packaging
}

\author{
M. Helena Gomes \\ $C B Q F$, Escola Superior de Biotecnologia do Porto, Universidade Católica \\ Portuguesa, Rua Dr. António Bernardino de Almeida, 4200-072 Porto, \\ Portugal
}

Randolph M. Beaudry

Department of Horticulture, Michigan State University, East Lansing, MI 48824-1325

\author{
Domingos P.F. Almeida ${ }^{1}$ \\ $C B Q F$, Escola Superior de Biotecnologia do Porto, Universidade Católica \\ Portuguesa, Rua Dr. António Bernardino de Almeida, 4200-072 Porto, \\ Portugal; and Faculdade de Ciências, Universidade do Porto, Rua Campo \\ Alegre, 687, 4169-007 Porto, Portugal
}

Additional index words. Cucumis melo, melon, minimally processed fruit, Michaelis-Menten kinetics

\begin{abstract}
The respiratory behavior of fresh-cut melon under modified atmosphere packaging at various temperatures was characterized to assess the potential for shelf life extension through low-oxygen and to generate information for the development of appropriate packaging conditions. Cantaloupe melon (Cucumis melo var. cantalupensis 'Olympic Gold') cubes were packaged and stored at $0,5,10$, and $15^{\circ} \mathrm{C}$. Packages attained gas equilibrium after 5 days at $10^{\circ} \mathrm{C}, 6$ days at $5^{\circ} \mathrm{C}$, and 10 days at $0^{\circ} \mathrm{C}$. In cubes stored at $15^{\circ} \mathrm{C}$, decay started before steady-state gas levels were reached. Respiration rates were measured and respiratory quotient calculated once steady-state $\mathrm{O}_{2}$ and $\mathrm{CO}_{2}$ partial pressures were achieved inside the packages. $\mathrm{O}_{2}$ uptake increased with temperature and $\mathrm{O}_{2}$ partial pressure $\left(\mathrm{pO}_{2} \mathrm{pkg}\right)$, according to a Michaelis-Menten kinetics described by $\boldsymbol{R}_{O_{2}}=$ $\left[\left(R_{O_{2}}{ }^{m a x}, T \times p O_{2} \mathrm{pkg}\right) /\left(K_{m, O_{2}}+p \mathrm{O}_{2} \mathrm{pkg}\right)\right]$. Respiratory parameters were modeled as an exponential function of temperature: $R_{O 2}=\left\{\left[1.34 \times 10^{-17} \times \mathrm{e}^{(0.131 \times \mathrm{T})} \times p \mathrm{O}_{2} \mathrm{pkg}\right] /\left[1.15 \times 10^{-24} \times\right.\right.$

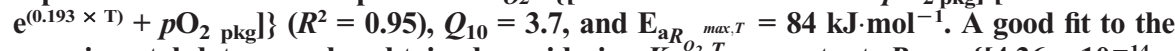
experimental data was also obtained considering $K_{m, O_{2}}^{T}$ as constant: $R_{O 2}=\left\{\left[4.36 \times 10^{-14} \times\right.\right.$

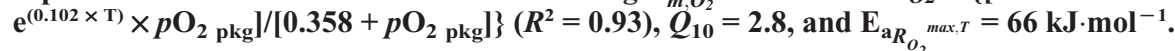
These results provide fundamental information to predict package permeability and steady-state $p \mathrm{O}_{2}$ pkg required to prevent anaerobic conditions and maximize shelf life of fresh-cut cantaloupe. The kinetics of respiration as a function of $\mathrm{pO}_{2}$ suggests that no significant reductions in respiration rate of fresh-cut cantaloupe can be achieved by lowering $\mathrm{O}_{2}$ levels.
\end{abstract}

Melons are large fruit whose preparation requires slicing and disposal of the rind and seeds. Therefore, convenience of consumption is valued in this fruit and, not surprisingly, fresh-cut melons account for a major part of the growing fresh-cut fruit market (Offner, 2011). Fresh-cut processing invariably involves tissue wounding with the

\footnotetext{
Received for publication 9 Jan. 2012. Accepted for publication 11 Apr. 2012.

This work was funded by Fundação para a Ciência e a Tecnologia, Portugal, and co-funded by POPH, European Social Fund, through project grant PTDC/ AGR-ALI/66144/2006 and the PhD grant SFRH/ BD/22628/2005 to M.H. Gomes.

${ }^{1}$ To whom reprint requests should be addressed; e-maildalmeida@fc.up.pt.
}

concomitant healing response. Wound response in plant tissues is mediated by ethylene and often involves increased respiration. Enhancement of respiration rate after cutting of cantaloupe mesocarp has been documented (McGlasson and Pratt, 1964), although the steady-state respiration rates of cut melon pieces can be similar to those of whole fruit under refrigeration (Aguayo et al., 2004; Watada et al., 1996).

Respiration rates have been reported for fresh-cut melons (cantaloupe and other cultivar groups) at various temperatures (Aguayo et al., 2004; Gorny, 1998; Watada et al., 1996) and were predicted under non-equilibrium gas concentrations for an inodorus-type melon ('Piel de Sapo') stored at $4{ }^{\circ} \mathrm{C}$ with initial oxygen partial pressures of $2.5,21$, and $70 \mathrm{kPa}$ (Oms-Oliu et al., 2008). During the first $10 \mathrm{~d}$ of storage at $4{ }^{\circ} \mathrm{C}$, the respiration rates of cut 'Piel de Sapo' ranged from $0.13 \mathrm{mmol}$ $\mathrm{CO}_{2} / \mathrm{kg} / \mathrm{h}$ to $0.83 \mathrm{mmol} \mathrm{CO} / \mathrm{kg} / \mathrm{h}$ (Oms-Oliu et al., 2008), values similar to those reported by Gorny (1998). For the same storage period at $5{ }^{\circ} \mathrm{C}$, Aguayo et al. (2004) measured respiration rates of 0.16 to $0.25 \mathrm{mmol} \mathrm{CO} / \mathrm{kg} / \mathrm{h}$ for cantaloupe and inodorus melons, values 1.5 to two times higher than those obtained at $0{ }^{\circ} \mathrm{C}$.

Modified atmosphere packaging (MAP) often complements refrigeration as an additional hurdle to help maintain the quality and food safety of fresh-cut fruit. The practical benefits of MAP are considered relevant for fresh-cut cantaloupe with favorable gas partial pressures ranging from 3 to $5 \mathrm{kPa} \mathrm{O}_{2}$ and 6 to $15 \mathrm{kPa} \mathrm{CO}_{2}$ (Gorny, 1998). Recommended gas compositions for MAP of fresh-cut produce in general and fresh-cut melon in particular have been established based on few published references (Gorny, 1998) and on experiments with a limited number of combinations of $\mathrm{O}_{2}$ and $\mathrm{CO}_{2}$ concentrations (Bai et al., 2001; Oms-Oliu et al., 2007). Optimal packaging geometry and film permeability to achieve the target gas levels can be deducted from the respiration rates (Jacxsens et al., 2000; Lakakul et al., 1999). However, despite the benefits observed in the few reports on MAP of fresh-cut melon (Bai et al., 2001, 2003; Oms-Oliu et al., 2007, 2008), an observation of the European and American markets for fresh-cut melon reveals that most operators do not aim at optimizing gas compositions inside the packages given that anaerobiosis is prevented. The discrepancy between the potential benefits of optimal MAP reported in the literature and the apparent lack of adoption of this knowledge by the industry may be the result of deficient knowledge transfer. Alternatively, the putative benefits of optimal MAP in fresh-cut melon fail to materialize in actual supply chains, and the efforts to achieve optimal MAP conditions have little or no economic benefit. Physiological limitations to the reduction of respiration rate by MAP must also be considered.

The reduction in respiration by MAP depends on the kinetics of the respiration rate as a function of oxygen partial pressure at given temperatures. In whole fruit, significant differences in the kinetic parameters are found among species (Beaudry, 2000; Hertog et al., 1999). Postharvest treatment of apple with the ethylene action inhibitor 1-methylcyclopropene, inducing changes in the ripening stage, significantly alters the kinetic parameters of respiration as a function of $\mathrm{O}_{2}$ substrate (Beaudry, 2000). The kinetics of respiration vs. oxygen concentration in fresh-cut 'Rocha' pear suggests that no significant reduction in respiration rate can be achieved through MAP (Gomes et al., 2010); consistent with this physiological limitation, no significant improvement of metabolism-dependent quality attributes was observed in fresh-cut pear under various MAP conditions (Gomes et al., unpublished data). Therefore, the fundamental knowledge of respiratory parameters as affected by $\mathrm{O}_{2}$ partial pressure is essential to establish the 
physiological limits of the tissue, to predict the benefits of low oxygen, and, eventually, to design packages aimed at targeted atmosphere conditions.

The objective of this study was to determine the effect of steady-state oxygen concentration on the respiration kinetics of fresh-cut cantaloupe at various temperatures, to provide detailed information to predict the benefits of MAP, and to assist in the design of adequate packages for this convenient product.

\section{Materials and Methods}

Plant material and processing conditions. Orange-fleshed cantaloupe melon (Cucumis melo L. subsp. melo var. cantalupensis Naudin 'Olympic Gold') fruit grown by Del Monte Fresh Produce Co. in Arizona were harvested in Nov. 2007, purchased from a broker in East Lansing, MI, and stored at $3{ }^{\circ} \mathrm{C}$ for a maximum of $48 \mathrm{~h}$ before use. Fruits ( $\mathrm{n}=14$ to 26 per temperature treatment) with an average weight of $2.5 \pm 0.2 \mathrm{~kg}$ and $11.7 \pm 1.5 \%(\mathrm{w} / \mathrm{w})$ soluble solids were used in the experiments. Whole fruit were rinsed with tap water, sanitized with $150 \mu \mathrm{L} \cdot \mathrm{L}^{-1} \mathrm{NaClO}$ for $2 \mathrm{~min}$, and air-dried. The rind was removed by hand with a sharp knife and the flesh was cut into trapezoidal sections $\approx 2 \times 2.5 \mathrm{~cm}$ wide.

Packaging and storage conditions. Melon pieces were placed in vented polyethylene terephthalate clamshells (Monte Package Company, Riverside, MI) of $13.0 \times 11.1 \times$ $6.7 \mathrm{~cm}$ that were inserted into low-density polyethylene (Dow Chemical Company, Midland, MI) pouches $(18.5 \times 19.0 \mathrm{~cm}$ or $18.5 \times 19.5 \mathrm{~cm})$, which were hermetically sealed using a heat sealer. Several combinations ( $\mathrm{n}=12$ per temperature treatment) of film surface area and film thickness, and a range of fruit masses varying from 0.04 to $0.36 \mathrm{~kg}$ per pouch, were used to assure a wide series of steady-state gas concentrations within the packages. The film thickness used in the experiments ranged from $28.1 \times 10^{-4}$ to $77.7 \times 10^{-4} \mathrm{~cm}$. Film permeabilities to $\mathrm{O}_{2}$ and $\mathrm{CO}_{2}$ (Table 1) were calculated with the predicting equations $P_{O 2}=0.067 \times \mathrm{e}^{(-4423 / \mathrm{T})}$ and $P_{\mathrm{CO} 2}=0.118 \times \mathrm{e}^{(-4153 / \mathrm{T})}$ derived from the diffusion rate of gases of known concentrations through the film inserted into a permeability cell and the Arrhenius model to account for the effect of temperature on permeability (Gomes et al., 2010). Three replicates of each of the 12 combination of film thickness, film area, and fruit mass were stored at $0,5,10$, and $15^{\circ} \mathrm{C}$.

Determination of respiration rate. The gas composition of the headspace in individual packages was monitored daily until steadystate was reached. Gas $(100 \mu \mathrm{L})$ was withdrawn from packages through a silicon sampling

Table 1. Film permeability to $\mathrm{O}_{2}$ and $\mathrm{CO}_{2}$ at various temperatures.

\begin{tabular}{lcc}
\hline Temperature $\left({ }^{\circ} \mathrm{C}\right)$ & $\begin{array}{c}\text { Permeability to } \mathrm{O}_{2} \\
\left(\mathrm{mmol} \cdot \mathrm{cm} \cdot \mathrm{cm}^{-2} \cdot \mathrm{h}^{-1} \cdot \mathrm{kPa}^{-1}\right)\end{array}$ & $\begin{array}{c}\text { Permeability to } \mathrm{CO}_{2} \\
\left(\mathrm{mmol} \cdot \mathrm{cm}^{-1} \mathrm{~cm}^{-1} \mathrm{~h}^{-1} \cdot \mathrm{kPa}^{-1}\right)\end{array}$ \\
\hline 0 & $6.23 \times 10^{-09}$ & $2.94 \times 10^{-08}$ \\
5 & $8.33 \times 10^{-09}$ & $3.86 \times 10^{-08}$ \\
10 & $1.10 \times 10^{-08}$ & $5.03 \times 10^{-08}$ \\
15 & $1.45 \times 10^{-08}$ & $6.48 \times 10^{-08}$ \\
\hline
\end{tabular}

septum (Gomes et al., 2010). Gases were measured using a paramagnetic $\mathrm{O}_{2}$ detector (Series 1100; Servomex Co., Sussex, U.K.) and an infrared $\mathrm{CO}_{2}$ detector (ADC 255-MK3; Analytical Development Co., Hoddesdon, U.K.) connected in series. Rates of $\mathrm{O}_{2}$ uptake $\left(R_{O_{2}}\right)$ and $\mathrm{CO}_{2}\left(R_{\mathrm{CO}_{2}}\right)$ production were calculated from Eq. [1] and Eq. [2] using steady-state $\mathrm{O}_{2}$ and $\mathrm{CO}_{2}$ partial pressures, package permeability, and fruit weight (Beaudry et al., 1992; Lakakul et al., 1999). Respiratory quotients $\left(R Q=R_{\mathrm{CO}_{2}} / R_{\mathrm{O}_{2}}\right)$ for aerobic respiration were computed from the calculated respiration rates.

$$
\begin{aligned}
R_{\mathrm{O}_{2}} & =\frac{\frac{P_{\mathrm{O}_{2}} \times A}{l} \times\left(p O_{2 a t m}-p O_{2 p k g}\right)}{\mathrm{M}} \\
R_{\mathrm{CO}_{2}} & =\frac{\frac{P_{\mathrm{CO}_{2}} \times A}{l} \times(1}{\left.\mathrm{M} C \mathrm{O}_{2 p k}-p C O_{2 a t m}\right)}
\end{aligned}
$$

where $R_{\mathrm{O}_{2}}$ and $\mathrm{R}_{\mathrm{CO}_{2}}$ are respiration rates $\left(\mathrm{mmol} \cdot \mathrm{kg}^{-1} \cdot \mathrm{h}^{-1}\right)$ for $\mathrm{O}_{2}$ and $\mathrm{CO}_{2}, P_{O_{2}}$ and $\mathrm{P}_{\mathrm{CO}_{2}}$ are the $\mathrm{O}_{2}$ and $\mathrm{CO}_{2}$ permeabilities $\left(\mathrm{mmol} \cdot \mathrm{cm} \cdot \mathrm{cm}^{-2} \cdot \mathrm{h}^{-1} \cdot \mathrm{kPa}^{-1}\right), \mathrm{A}$ is the film area $\left(\mathrm{cm}^{2}\right), 1$ is the film thickness $(\mathrm{cm}), p \mathrm{O}_{2}$ atm, $p \mathrm{O}_{2}$ pkg, $p \mathrm{CO}_{2}$ atm, and $p \mathrm{CO}_{2}$ pkg are $\mathrm{O}_{2}$ and $\mathrm{CO}_{2}$ partial pressure $(\mathrm{kPa})$ outside $(\mathrm{atm})$ and inside $\left({ }_{\mathrm{pkg}}\right)$ the package, and $\mathrm{M}$ is the fruit mass $(\mathrm{kg})$.

Experimental data modeling. Respiration rate $\left(R_{\mathrm{O}_{2}}\right)$ was described as a function of $\mathrm{O}_{2}$ partial pressure by a Michaelis-Menten model [Eq. (3)] as described by Lee et al. (1991).

$$
R_{O_{2}}=\frac{R_{O_{2}}{ }^{\max , T} \times p O_{2 p k g}}{K_{m, O_{2}}{ }^{T}+p O_{2 p k g}}
$$

where $R_{O_{2}}{ }^{\max , T}$ is the maximal rate of $R_{O_{2}}$ $\left(\mathrm{mmol} \cdot \mathrm{kg}^{-1} \cdot \mathrm{h}^{-1}\right), p \mathrm{O}_{2} \mathrm{pkg}$ is the oxygen partial pressure inside packages $(\mathrm{kPa})$, and $K_{m, O_{2}}{ }^{T}$ is $p \mathrm{O}_{2}$ pkg at half the value of $R_{\mathrm{O}_{2}}{ }_{\max , T}(\mathrm{kPa})$.

The Michaelis-Menten model was fitted to the data from temperatures between 0 and $10{ }^{\circ} \mathrm{C}(\mathrm{n}=66)$ but not at $15^{\circ} \mathrm{C}$ because fruit started to decay before reaching steady-state. The maximal respiration rate was found to be an exponential function of temperature $\left[R_{O_{2}}^{\max , T}=\mathrm{a} \times \mathrm{e}^{(\mathrm{b} \times \mathrm{T})}\right]$, and the MichaelisMenten constant was modeled as either an exponential function of temperature $\left[K_{m, O_{2}}{ }^{T}=\right.$ $\left.\mathrm{q} \times \mathrm{e}^{(\mathrm{r} \times \mathrm{T})}\right]$ or a constant (Table 2). Parameter estimates ( $a, b, q$, and $r$ ) were obtained by non-linear regression using the LevenbergMarquardt method. The model predictions of respiratory parameters (Table 2) were computed at 0,5 , and $10{ }^{\circ} \mathrm{C}$ and were used to calculate activation energies through an Arrhenius plot (Gomes et al., 2010) and the temperature coefficient $\left(Q_{10}\right)$.
Accuracy of the parameter estimates was calculated as the ratio between SE and estimated value. Differences between the simulated and the experimental results were ascertained by the root mean square error (RMSE) (Yang and Chinnan, 1988). All statistical analyses were performed using the software package SPSS for Windows Version 16.0 (SPSS, Chicago, IL).

\section{Results and Discussion}

Effect of oxygen concentration and temperature on respiration rate. Packages with fresh-cut melon attained gas equilibrium after $5 \mathrm{~d}$ at $10^{\circ} \mathrm{C}, 6 \mathrm{~d}$ at $5^{\circ} \mathrm{C}$, and $10 \mathrm{~d}$ at $0{ }^{\circ} \mathrm{C}$, but steady-state was not reached at $15{ }^{\circ} \mathrm{C}$ because the tissue started to decay. Experimentally determined respiration rates $\left(R_{O_{2}}\right.$ and $R_{\mathrm{CO}_{2}}$ ) between 0.1 and $16.2 \mathrm{kPa} \mathrm{O}$ (Table 3) are within the range reported in the literature for fresh-cut cantaloupe (Aguayo et al., 2004; Gorny, 1998). The reported respiration rates of fresh-cut cantaloupe melon are 0.09 to $0.36,0.13$ to $0.71,0.27$, and $1.34 \mathrm{mmol} \mathrm{CO} / \mathrm{kg} / \mathrm{h}$ at $0,5,10$, and $20^{\circ} \mathrm{C}$, respectively (Gorny, 1998).

RQ of fresh-cut cantaloupe melon stored at various temperatures ranged from 1.6 at $0{ }^{\circ} \mathrm{C}$ to 3.1 at $15^{\circ} \mathrm{C}$ (Table 3; Fig. 1 ). The RQ values observed are higher than the theoretical value of 1.3 for the oxidation of organic acids (Kader et al., 1989) that would be expected in melon fruit, in which malic and citric acids are dominant (Lamikanra et al., 2000). The higher RQ values obtained in our study at suboptimal temperatures are likely a sign of slight fermentation at steady-state oxygen concentrations. This is not uncommon in fresh-cut melons, in which the loss of malic acid at $20^{\circ} \mathrm{C}$ can be related to malolactic fermentation by the lactic acid bacteria (Lamikanra et al., 2000). Also, in fresh-cut 'Piel de Sapo' melon stored at $4{ }^{\circ} \mathrm{C}$ under $21 \mathrm{kPa} \mathrm{O}_{2}$ and $2.5 \mathrm{kPa} \mathrm{O}_{2}+7 \mathrm{kPa} \mathrm{CO}$, the $\mathrm{RQ}$ increases during storage in association with ethanol production (Oms-Oliu et al., 2008). In addition, the rise in $\mathrm{CO}_{2}$ production observed in fresh-cut honeydew after $3 \mathrm{~d}$ at $10{ }^{\circ} \mathrm{C}$ or $6 \mathrm{~d}$ at $5{ }^{\circ} \mathrm{C}$ was attributed to tissue deterioration (Qi et al., 1999).

Fermentation occurred at higher oxygen partial pressure as the storage temperature increased from 0 to $10{ }^{\circ} \mathrm{C}$ (Table 3; Fig. 1), consistent with previous observations in other fruit (Beaudry et al., 1992; Lakakul et al., 1999). To avoid anaerobic respiration in honeydew melon, oxygen partial pressure must be increased from $2 \mathrm{kPa} \mathrm{O}_{2}$ at $5{ }^{\circ} \mathrm{C}$ to $4 \mathrm{kPa} \mathrm{O}_{2}$ at $10^{\circ} \mathrm{C}$ (Qi et al., 1999). Our results indicate that fresh-cut cantaloupe melon should be packaged with oxygen partial pressure higher than $0.7 \mathrm{kPa}$ at $0{ }^{\circ} \mathrm{C}$ and $1.3 \mathrm{kPa}$ at 5 and $10{ }^{\circ} \mathrm{C}$ to prevent fermentation. At these oxygen concentrations, carbon dioxide levels were $7.6,11.3$, and $14.0 \mathrm{kPa}$ at 0,5 , and $10^{\circ} \mathrm{C}$ (Fig. 1), respectively. Package atmospheres commonly considered potentially beneficial to the quality of cantaloupe cubes require higher levels of oxygen, usually 
Table 2. Best estimates of $R_{O_{2}}{ }^{\max , T}$ and $K_{m, O_{2}}{ }^{T}$ for fresh-cut cantaloupe melon as a function of temperature $(\mathrm{K})$ and corresponding model accuracies.

\begin{tabular}{|c|c|c|c|c|c|c|c|}
\hline Model $^{\mathrm{z}}$ & $R_{\mathrm{O}_{2}}{ }^{\max , T}\left(\mathrm{mmol} \cdot \mathrm{kg}^{-1} \cdot \mathrm{h}^{-1}\right)$ & $K_{m, O_{2}}{ }^{T}(\mathrm{kPa})$ & $R^{2}$ & RMSE & $Q_{10}$ & $\begin{array}{c}E_{a R_{O_{2}}{ }_{m a x}, \mathrm{y}} \\
\left(\mathrm{kJ} \cdot \mathrm{mol}^{-1}\right)\end{array}$ & 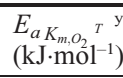 \\
\hline$\overline{\mathrm{MM}}$ & $1.34 \times 10^{-17} \mathrm{e}^{0.131 \times \mathrm{T}}$ & $1.15 \times 10^{-24} \mathrm{e}^{0.193 \times \mathrm{T}}$ & 0.949 & 0.011 & 3.7 & 84.3 & 124.2 \\
\hline $\mathrm{MM}_{\mathrm{k}}$ & $4.36 \times 10^{-14} \mathrm{e}^{0.102 \times \mathrm{T}}$ & 0.358 & 0.929 & 0.013 & 2.8 & 65.6 & - \\
\hline
\end{tabular}

Table 3. Experimental rates of $\mathrm{O}_{2}$ uptake and $\mathrm{CO}_{2}$ production, respiratory quotient and fermentation threshold for packaged fresh-cut cantaloupe melon stored at various temperatures.

\begin{tabular}{lcccc}
\hline Temperature $\left({ }^{\circ} \mathrm{C}\right)$ & $\begin{array}{c}R_{\mathrm{O}_{2}} \text { range } \\
\left(\mathrm{mmol} \cdot \mathrm{kg}^{-1} \cdot \mathrm{h}^{-1}\right)\end{array}$ & $\begin{array}{c}R_{\mathrm{CO}_{2}} \text { range } \\
\left(\mathrm{mmol} \cdot \mathrm{kg}^{-1} \cdot \mathrm{h}^{-1}\right)\end{array}$ & $\begin{array}{c}\text { Respiratory } \\
\text { quotient }\end{array}$ & $\begin{array}{c}\text { Fermentation } \\
\text { threshold }(\mathrm{kPa})\end{array}$ \\
\hline 0 & $0.03-0.07$ & $0.07-0.12$ & $1.63 \pm 0.03$ & 0.74 \\
5 & $0.04-0.11$ & $0.13-0.20$ & $1.94 \pm 0.07$ & 1.33 \\
10 & $0.06-0.19$ & $0.26-0.43$ & $2.43 \pm 0.11$ & 1.35 \\
15 & $0.09-0.80$ & $0.62-2.39$ & $3.12 \pm 0.05$ & 1.07 \\
\hline
\end{tabular}

${ }^{2} \mathrm{RQ}$ are the mean \pm SE of the experimental values under aerobic respiration $(\mathrm{n}=11$ to 18$)$ measured at oxygen concentrations ranging from $16.2 \mathrm{kPa}$ to the fermentation threshold (Fig. 1).
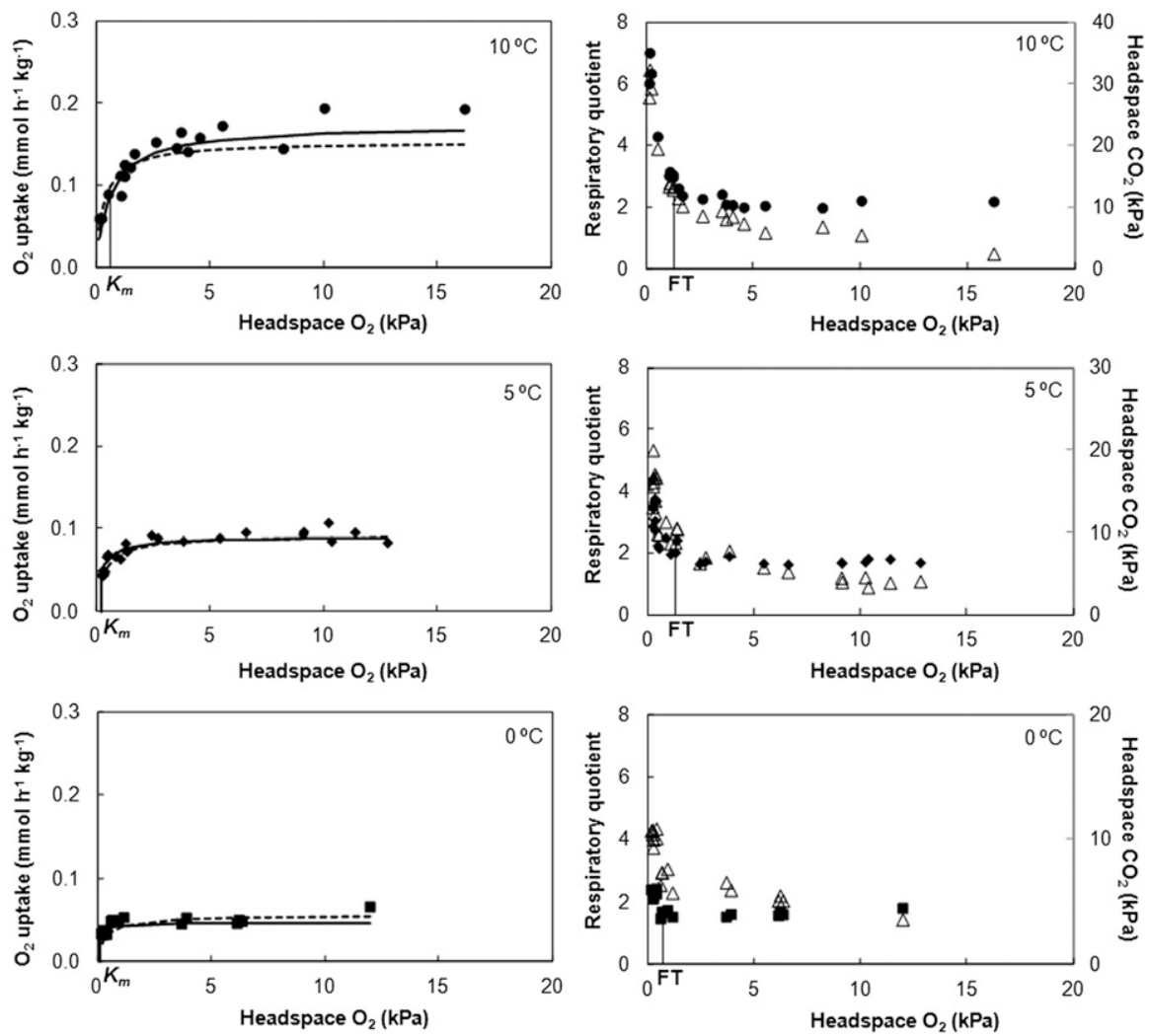

Fig. 1. Effect of steady-state $\mathrm{O}_{2}$ partial pressure and storage temperature on the rate of $\mathrm{O}_{2}$ uptake (left) by cantaloupe pieces in sealed packages and corresponding respiratory quotient (right) and headspace $\mathrm{CO}_{2}$ (open triangles). On the left, solid lines represent the MM model fit, whereas dashed lines represent the $\mathrm{MM}_{\mathrm{k}}$ model fit. The oxygen partial pressures at which respiration reaches half its maximum (apparent $K_{m}$ ) and the fermentation threshold (FT) are indicated with a vertical bar.

$\approx 3$ to $5 \mathrm{kPa} \mathrm{O}$ combined with 6 to $15 \mathrm{kPa}$ $\mathrm{CO}_{2}$ (Gorny, 1998). Similar gas mixtures have been tested by other authors with freshcut cantaloupe or honeydew melon, e.g., $4 \mathrm{kPa} \mathrm{O}_{2}+10 \mathrm{kPa} \mathrm{CO}_{2}$ (Bai et al., 2001), $5 \mathrm{kPa} \mathrm{O}_{2}+10 \mathrm{kPa} \mathrm{CO}$ (Amaro et al., 2012), $5 \mathrm{kPa} \mathrm{O}_{2}+5 \mathrm{kPa} \mathrm{CO}$ (Bai et al., 2003), $2.5 \mathrm{kPa} \mathrm{O}_{2}+7 \mathrm{kPa} \mathrm{CO}$ (Oms-Oliu et al., 2007), and 2 to $4 \mathrm{kPa} \mathrm{O}_{2}+10 \mathrm{kPaCO}_{2}$ (Qi et al., 1999).
Modeling the effect of oxygen concentration and temperature on respiration rate. Oxygen uptake rate increased with temperature and $p \mathrm{O}_{2 \mathrm{pkg}}$ in a way consistent with MichaelisMenten kinetics (Fig. 1). Respiratory parameters were modeled as exponential functions of temperature (Cameron et al., 1994). Alternatively, $K_{m, O_{2}}^{T}$ was treated as constant coupled with $R_{O_{2}}$ max,T as an exponential function of temperature (Hertog et al., 1998; Jacxsens et al., 2000). These models provided a good fit to the experimental data (Fig. 1) as assessed by the RMSE (Table 2). The fit was slightly poorer $(\mathrm{RMSE}=0.013)$ when $K_{m, O_{2}}^{T}$ was taken as constant $\left(\mathrm{MM}_{\mathrm{k}}\right)$, and a deviation from experimental data was observed at high $\mathrm{O}_{2}$ partial pressures at $10{ }^{\circ} \mathrm{C}$ (Fig. 1).

Maximal $\mathrm{O}_{2}$ uptake rate is highly dependent on the temperature. The activation energy was estimated at 66 to $84 \mathrm{~kJ} \cdot \mathrm{mol}^{-1}$ (Table 2) and the $Q_{10}$ was from 2.8 to 3.7 (Table 2). $Q_{10}$ values of 3.3 to 3.6 for cubes of muskmelon and honeydew melons have been reported in the interval 0 to $10{ }^{\circ} \mathrm{C}$ (Watada et al., 1996) and a $Q_{10}$ of 3.1 can be computed for whole cantaloupe melon from the data compiled by Exama et al. (1993). Activation energy of intact produce generally range from 50 to $89 \mathrm{~kJ} \cdot \mathrm{mol}^{-1}$ (Exama et al., 1993; Fonseca et al., 2002) and is often higher for fresh-cut produce (Gomes et al., 2010; Jacxsens et al., 2000).

Respiratory responses to low oxygen and implications for modified atmosphere packaging. A positive difference between $K_{m, O_{2}}{ }^{T}$ for $\mathrm{O}_{2}$ uptake and the fermentation thresholdnamed "safe working atmosphere" by Beaudry (2000) — can be taken as an indicator that significant decreases in metabolic activity can be obtained through the reduction in oxygen partial pressure. To reduce the respiration rate of fresh-cut cantaloupe by $50 \%$, oxygen partial pressure must be less than $0.6 \mathrm{kPa}$, values lower than the fermentation threshold of $0.7 \mathrm{kPa}$ at $0{ }^{\circ} \mathrm{C}$ (Table 4; Fig. 1). Therefore, a safe working atmosphere does not exist for fresh-cut cantaloupe, and limited extension of shelf life is anticipated through the reduction of oxygen levels. A similar response was found in packed strawberry fruits (Hertog et al., 1999) and fresh-cut 'Rocha' pear (Gomes et al., 2010) suggesting that low-oxygen MAP provides little or no benefit to extend quality attributes that depend on the metabolic rate of these commodities. Consistently, color, firmness, and soluble solids content of fresh-cut cantaloupe were unaffected by oxygen levels (Amaro et al., 2012). However, the production of flavor-important esters is favored under high oxygen levels (16 to $18 \mathrm{kPa}$ ) and suppressed at $5 \mathrm{kPa} \mathrm{O}_{2}$, suggesting that high oxygen is required for desirable aroma revelation by fresh-cut cantaloupe (Amaro et al., 2012).

If this assumption proves correct, the potential benefits of MAP reported for fresh-cut cantaloupe (Gorny, 1998) are not attributable to the low oxygen levels; instead, they are likely explained by the high $\mathrm{CO}_{2}$ partial pressure, reduced water loss, and lower microbial contamination resulting from the package barrier.

In conclusion, the respiratory parameters reported here suggest that there is a physiological limitation to the extension of shelf life of fresh-cut cantaloupe through the reduction of oxygen partial pressure, justifying the limited attention of the industry operators to the optimization of MAP for oxygen levels as long as the tissue is under aerobic conditions. 
Table 4. Parameter best estimates for fresh-cut cantaloupe melon stored at various temperatures.

\begin{tabular}{ccccccc}
\hline & & \multicolumn{2}{c}{ MM } & & \multicolumn{2}{c}{$\mathrm{MM}_{\mathrm{k}}$} \\
\cline { 3 - 4 } \cline { 6 - 7 } $\begin{array}{c}\text { Temperature } \\
\left({ }^{\circ} \mathrm{C}\right)\end{array}$ & $\begin{array}{c}\text { Fermentation } \\
\text { threshold }(\mathrm{kPa})\end{array}$ & $K_{m, O_{2}{ }^{T}(\mathrm{kPa})}$ & $\begin{array}{c}\text { Safe working } \\
\text { atmosphere }(\mathrm{kPa})\end{array}$ & $K_{m, O_{2}}{ }^{T}(\mathrm{kPa})$ & $\begin{array}{c}\text { Safe working } \\
\text { atmosphere }(\mathrm{kPa})\end{array}$ \\
\hline 0 & 0.735 & 0.090 & No & & 0.358 & No \\
5 & 1.330 & 0.236 & No & & 0.358 & No \\
10 & 1.346 & 0.620 & No & & 0.358 & No \\
\hline
\end{tabular}

\section{Literature Cited}

Aguayo, E., V.H. Escalona, and F. Artés. 2004. Metabolic behaviour and quality changes of whole and fresh processed melon. J. Food Sci. 69:148-155.

Amaro, A.L., J.C. Beaulieu, C.C. Grimm, R.E. Stein, and D.P.F. Almeida. 2012. Effect of oxygen on aroma volatiles and quality of fresh-cut cantaloupe and honeydew melons. Food Chem. 130:49-57.

Bai, J.H., R.A. Saftner, and A.E. Watada. 2003. Characteristics of fresh-cut honeydew (Cucumis $\times$ melo $\mathrm{L}$.) available to processors in winter and summer and its quality maintenance by modified atmosphere packaging. Postharvest Biol. Technol. 28:349-359.

Bai, J.H., R.A. Saftner, A.E. Watada, and Y.S. Lee. 2001. Modified atmosphere maintains quality of fresh-cut cantaloupe (Cucumis melo L.). J. Food Sci. 66:1207-1211.

Beaudry, R.M. 2000. Responses of horticultural commodities to low oxygen: Limits to the expanded use of modified atmosphere packaging. HortTechnology 10:491-500.

Beaudry, R.M., A.C. Cameron, A. Shirazi, and D.L. Dostal-Lange. 1992. Modified-atmosphere packaging of blueberry fruit: Effect of temperature on package $\mathrm{O}_{2}$ and $\mathrm{CO}_{2}$. J. Amer. Soc. Hort. Sci. 117:436-441.

Cameron, A.C., R.M. Beaudry, N.H. Banks, and M.V. Yelanich. 1994. Modified-atmosphere packaging of blueberry fruit: Modeling respiration and package oxygen partial pressures as a function of temperature. J. Amer. Soc. Hort. Sci. 119:534-539.
Exama, A., J. Arul, R.W. Lencki, L.Z. Lee, and C. Toupin. 1993. Suitability of plastic films for modified atmosphere packaging of fruits and vegetables. J. Food Sci. 58:1365-1370.

Fonseca, S.C., F.A.R. Oliveira, and J.K. Brecht. 2002. Modelling respiration rate of fresh fruits and vegetables for modified atmosphere packages: A review. J. Food Eng. 52:99-119.

Gomes, M.H., R.M. Beaudry, D.P.F. Almeida, and F.X. Malcata. 2010. Modelling respiration of packaged fresh-cut 'Rocha' pear as affected by oxygen concentration and temperature. J. Food Eng. 96:74-79.

Gorny, J.R. 1998. A summary of CA and MA requirements and recommendations for freshcut (minimally processed) fruits and vegetables, p. 30-66. In: Gorny, J.R. (ed.). Proc. of $7^{\text {th }}$ Intl Controlled Atmosphere Res. Conf., Vol. 5. Davis, CA.

Hertog, M.L.A.T.M., H.A.M. Boerrigter, G.J.P.M. van den Boogaard, L.M.M. Tijskens, and A.C.R. van Schaik. 1999. Predicting keeping quality of strawberries (cv 'Elsanta') packed under modified atmospheres: An integrated model approach. Postharvest Biol. Technol. $15: 1-12$.

Hertog, M.L.A.T.M., H.W. Peppelenbos, R.G. Evelo, and L.M.M. Tijskens. 1998. A dynamic and generic model of gas exchange of respiring produce: The effects of oxygen, carbon dioxide and temperature. Postharvest Biol. Technol. 14:335-349.

Jacxsens, L., F. Devlieghere, T.D. Rudder, and J. Debevere. 2000. Designing equilibrium modified atmosphere packages for fresh-cut vegetables subjected to changes in temperature. Lebensm. Wiss. Technol. 33:178-187.

Kader, A.A., D. Zagory, and E. Kerbel. 1989. Modified atmosphere packaging of fruits and vegetables. Crit. Rev. Food Sci. Nutr. 28: $1-30$.

Lakakul, R., R.M. Beaudry, and R.J. Hernandez. 1999. Modeling respiration of apple slices in modified-atmosphere packages. J. Food Sci. 64:105-110.

Lamikanra, O., J.C. Chen, D. Banks, and P.A. Hunter. 2000. Biochemical and microbial changes during storage of minimally processed cantaloupe. J. Agr. Food Chem. 48:5955-5961.

Lee, D.S., P.E. Haggar, J. Lee, and K.L. Yam. 1991. Model for fresh produce respiration in modified atmospheres based on principles of enzyme kinetics. J. Food Sci. 56:1580-1585.

McGlasson, W.B. and H.K. Pratt. 1964. Effects of wounding on respiration and ethylene production by cantaloupe fruit tissue. Plant Physiol. 39:128-132.

Offner, J. 2011. Convenience factor helps sell melons at retail. The Packer. 15 Apr. 2011.

Oms-Oliu, G., R. Soliva-Fortuny, and O. MartínBelloso. 2007. Effect of ripeness on the shelflife of fresh-cut melon preserved by modified atmosphere packaging. Eur. Food Res. Technol. 225:301-311.

Oms-Oliu, G., R. Soliva-Fortuny, and O. MartínBelloso. 2008. Modeling changes of headspace gas concentrations to describe the respiration of fresh-cut melon under low or superatmospheric oxygen atmospheres. J. Food Eng. 85: 401-409.

Qi, L., T. Wu, and A.E. Watada. 1999. Quality changes of fresh-cut honeydew melons during controlled atmosphere storage. J. Food Qual. 22:513-521.

Watada, A.E., N.P. Ko, and D.A. Minott. 1996 Factors affecting quality of fresh-cut horticultural products. Postharvest Biol. Technol. 9: $115-125$.

Yang, C.C. and M.S. Chinnan. 1988. Modeling the effect of $\mathrm{O}_{2}$ and $\mathrm{CO}_{2}$ on respiration and quality of stored tomatoes. Trans. ASAE 31: 920-925. 